Бойко Александр Петрович, канд. с.-х. наук, $\partial u-$ ректор, Адлерская опытная станция. Россия.

353341, г. Адлер, ул. Ленина, 95.

Тел.: (8862) 25-85-53; e-mail: aos.vir@mail.ru.

Стрижков Николай Иванович, $\partial-p$ c.- $x$. наук, гл. научный сотрудник, ФГБНУ «НИИСХ Юго-Востока». Россия.

410010, г. Саратов, ул. Тулайкова, 7.

Тел.: (8452) 64-74-39.
Критская Елена Евгеньевна, канд. с.-х. наук, доиент кафедры «Защита растений и плодоовощеводство», Саратовский государственный аграрный университет имени Н.И. Вавилова. Россия.

410012, г. Саратов, Театральная пл., 1.

Тел.: (8452) 27-20-70; e-mail:minkleit@yandex.ru.

Ключевые слова: яровая твердая пшенииа; сорняки; болезни; вредители; гербициды; фунгициды; протравители семян; инсектициды; урожай.

\title{
TECHNOLOGY OF SPRING DURUM WHEAT CULTIVATION WITH APPLICATION OF SECATOR TURBO, BAR-ITON, FALCON, NAGRO AND OTHERS
}

Spiridonov Yuriy Yakovlevich, Doctor of Biological Sciences, Professor, Head of the de-partment of Herbology, All-Russian Research Institute for Phytopathology. Russia.

Budynkov Nikolay Ivanovich, Candidate of Biological Sciences, Leading Researcher, All-Russian Research Institute for Phytopathology. Russia.

Boyko Aleksandr Petrovich, Candidate of Agricultural Sciences, Director, Adler Experi-mental Station. Russia.

Strizhkov Nikolay Ivanovich, Doctor of Agricultural Sciences, Chief Researcher, Agricul-tural Research Institute for South-East Region. Russia.

Kritskaya Elena Evgenyevna, Candidate of Agricultural Sciences, Associate Professor of the chair "Plant Protection and Horticulture", Saratov State Agrarian University named after N.I. Vavilov. Russia

Keywords: spring durum wheat; weed; diseases; pest; herbicides; fungicides; seed dress-er; insecticides; yield.

It has been described the possibility of a significant increase in the yield of spring durum wheat of the Saratovskaya Zolotistaya variety due to the integrated use of chemical plant pro-tection products. During four years of studies it has been studied of complex effect of preparations on the phytosanitary state of crops, yields and products' quality in Povolzhye. High results in pests $\backslash$ control were obtained after complex application of Bariton disinfectant $(1.5 l / h a)$, herbicides Secator Turbo (0.8l/ha) + Puma Super (75 $0.9 l / h a)$, fungicide Falkon $(0.6 \mathrm{l} / \mathrm{ha})$, insecticides Confidor Extra $(50 \mathrm{~g} /$ ha) + Decis Profi $(15 \mathrm{~g} / \mathrm{ha})$. In the experimen-tal variants, the incidence of root rot was 3.3 times less than in the control. Biological effec-tiveness against brown

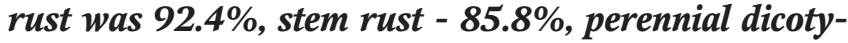
ledonous plants - $87.3 \%$, annual dicotyledonous plants - 94.0\%, annual monocotyledonous plants - 97.7\%. The total contamination decreased by $94.1 \%$. Treatment of crops with insecticides against larvae and adult thrips, sunn pest was 89.0 and $95.2 \%$. Set of measures against harmful organisms increased significantly crop yields. The best results were obtained after complex application of disinfectant, herbicides, fungicide, insecticides - 56.6\%; slightly less - $45.2 \%$ after application of a disinfectant, herbicide and insecticide. Application of disinfectant, fungicide and insecti-cide contributed to the preservation of $26.2 \%$ of the crop. The smallest increases were ob-tained after application of disinfectant and an insecticide - $14.9 \%$. Chemical protection not only preserved the crop, but also improved the quality of the products. The protein content in-creased from 12.5 to $14.4 \%$, gluten content - from 24.5 to $29.1 \%$

\section{ЗООГЕОГРАФИЧЕСКИЙ АНАЛИЗ СЛЕПНЕЙ СРЕДНЕЙ ТАЙГИ ЗАПАДНОЙ СИБИРИ}

\author{
ТЮМАСЕВА Зоя Ивановна, Южно-Уральский государственный \\ гуманитарно-педагогический университет \\ ДУХИН Владислав Васильевич, Инженерно-технический центр, г. Сургут \\ ГУСЬКОВА Елена Владимировна, Алтайский государственный университет
}

Проведен зоогеографический анализ слепней средней тайги Западной Сибири. Дана зоогеографическая характеристика слепней изучаемого региона. Отмечено шесть трансголарктических бореальных видов слепней; семь видов относятся к трансевразиатским; наибольшее количество видов (21) для средней тайги являются западно-центрально-палеарктическими. Проведен сравнительный анализ фаун слепней Томской области и ХМАО-Югры.

Ллепни (Diptera, Tabanidae) являют-

ся одним из важных компонентов гнуса, широко распространенных в природе семейств двукрылых насекомых. В мировой фауне их насчитывается около 3500 видов, в России зарегистрировано 176 видов [5]. Слепни встречаются во всех ландшафтных зонах России, кроме полярных широт. 
Укусы, наносимые слепнями, причиняют сильное беспокойство, как людям, так и животным. При массовых нападениях слепней резко снижается продуктивность сельскохозяйственных животных [1], а в некоторых местах, в период массового нападения слепней, прекращается дневной выпас скота. Они имеют большое эпизоотологическое значение, экспериментально доказано, что слепни принимают участие в механической передаче возбудителей инфекционных, протозойных и глистных заболеваний [6]. Поэтому для организации борьбы с ними, требуется более глубокое и детальное изучение этого семейства. Поскольку слепни являются свободноживущими насекомыми, то их распространение зависит от климатических факторов, типа растительности и от водоемов, в которых развиваются преимагинальные стадии слепней.

Цель исследования - провести зоогеографический анализ слепней средней тайги Западной Сибири; дать зоогеографическую характеристику этих насекомых.

Методика исследований. Фаунистические сборы слепней проводили с 2004 по 2015 г. на территории средней тайги Западной Сибири. Для этого использовали чучелообразные каркасные ловушки [8], бескаркасные шатровые ловушки [5], энтомологические сачки со съемными мешочками [3] для отлова самок слепней около животных и человека. Также использовали маршрутный метод сбора погибших и оглушенных насекомых с обочин крупных автомобильных дорог. Кроме того, слепней собирали на окнах помещений и в автомобилях. Идентификацию видов осуществляли на основании определителей насекомых. Весь собранный материал хранится в личной коллекции В.В. Духина (г. Сургут) и в научной энтомологической лаборатории профессора 3.И. Тюмасевой (г. Челябинск).

Для исследования зоогеографического характера фауны слепней нами взята за основу классификация ареалов насекомых К.Б. Городкова [2].

Результаты исследований. Несмотря на то, что климатические факторы определяют границы природных ландшафтных зон, однако при тщательном исследовании ареала «не удается обнаружить четкую приуроченность его к зональным границам, что часто постулируется при зоогеографических построениях» [2]. В табл. 1 представлена зоогеографическая характеристика фауны слепней средней тайги Западной Сибири.

I. Трансголарктические виды

К этой группе относятся виды, распро- страненные в Палеарктике и Неарктике, в соответствующем широтном поясе. Для средней тайги отмечено шесть трансголарктических бореальных видов - Ch. nigripes, $H$. aequetincta, $H$. arpadi, $H$. lurida, $H$. sexfasciata, T. lapponicus. Виды с этим типом ареала составляют $14 \%$ от всей фауны слепней изучаемого региона. Среди них можно отметить:

Ch. nigripes - типичный таежный вид. Встречается от Северной Европы до Камчатки и Сахалина. На севере отмечен в низовьях р. Оби. На территории средней тайги Западной Сибири встречается повсеместно.

H. aequetincta - по данным Н.Г. Олсуфьева [6], этот вид является тундровым. Граница ареала распространения в Западной Сибири проходит по северной тайге. Для средней тайги Западной Сибири этот вид отмечает 3.Г. Сабиров [7].

H. arpadi - также встречается на протяжении всей Евразии, в Север-Восточном Китае, Японии, Северной Америке. В наших сборах является субдоминантом.

H. lurida - широко распространен по всей Евразии в пределах таежной и отчасти лесной зон, также встречается в Северной Америке. В наших сборах этот вид является доминантом.

H. sexfasciata - по данным Н.Г. Олсуфьева [6], описан вид из Северной Америки (Аляска). Ареал обитания изучен недостаточно ввиду смешения с H. kauri. Достоверно известен вид из следующих мест: Северный Урал, север Тюменской области, Томская область, Алтай. Также встречается в Северной Скандинавии, Северной и Восточной Монголии, Северной Америке. На территории средней тайги Западной Сибири отмечен только в Томской области в единичном экземпляре.

T. lapponicus - распространен по всей территории Евразии, Японии, в Северо-Восточном Китае. Также отмечается и для Северной Америки. В наших сборах встречается в небольших количествах.

II. Трансевразиатские виды

Ареалы трансевразиатских видов простираются почти через всю Евразию. В средней тайге Западной Сибири встречается семь таких видов, из которых два - бореальные (Ch. divaricatus, H. tarandina), три - бореомонтанные (H. bimaculata, $H$. distinguenda, H. nigricornis), один - температный (H. montana). Виды с этим типом арела составляют 14 \% от фауны слепней, зарегистрированных на данной территории.

Ch. divaricatus - вид, широко распространенный в пределах таежной и лесной зон Ев- 
Зоогеографическая характеристика фауны слепней средней тайги Западной Сибири

\begin{tabular}{|c|c|c|c|c|}
\hline \multicolumn{2}{|c|}{ Характер распространения } & \multirow[b]{2}{*}{ Вид слепней } & \multirow{2}{*}{ 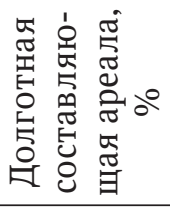 } & \multirow{2}{*}{ 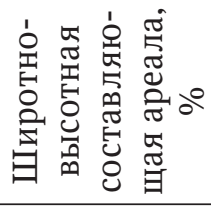 } \\
\hline Долготная составляющая ареала & $\begin{array}{c}\text { Широтно-высотная } \\
\text { составляющая } \\
\text { ареала }\end{array}$ & & & \\
\hline $\begin{array}{l}\text { Трансголарктические } \\
\text { (6) }\end{array}$ & $\begin{array}{l}\text { Бореальные } \\
\text { (6) }\end{array}$ & $\begin{array}{l}\text { Ch. nigripes } \\
\text { H. aequetincta } \\
\text { H. arpadi } \\
\text { H. lurida } \\
\text { H. sexfasciata } \\
\text { T. lapponicus }\end{array}$ & 14 & 14 \\
\hline \multirow{3}{*}{ Трансевразиатские (6) } & Бореальные (2) & $\begin{array}{l}\text { Ch. divaricatus } \\
H . \text { tarandina }\end{array}$ & 5 & \multirow{3}{*}{14} \\
\hline & Бореомонтанные (3) & $\begin{array}{l}\text { H. bimaculata } \\
\text { H. distinguenda } \\
\text { H. nigricornis }\end{array}$ & 7 & \\
\hline & Температные (1) & H. montana & 2 & \\
\hline $\begin{array}{l}\text { Западно-центрально-палеаркти- } \\
\text { ческие (21) }\end{array}$ & & & & 49 \\
\hline Евро-сибиро-среднеазиатские (4) & Температные (4) & $\begin{array}{l}\text { Ch. relictus } \\
\text { T. autumnalis } \\
\text { T. bromius } \\
\text { T. glaucopis }\end{array}$ & 9 & 9 \\
\hline \multirow[t]{3}{*}{ Евро-обские (10) } & Температные (8) & $\begin{array}{l}\text { Ch. rufipes } \\
\text { Ch. sepulcralis } \\
\text { Hm. subcylindrica } \\
\text { Hm. pluvialis } \\
\text { Hp. pellucens } \\
\text { T. bovinus } \\
\text { T. maculicornis } \\
\text { A. rusticus }\end{array}$ & 19 & \multirow[t]{3}{*}{23} \\
\hline & Бореальные (1) & $\begin{array}{l}\text { H. nitidifrons con- } \\
\text { fiformis }\end{array}$ & 2 & \\
\hline & Полизональные (1) & T. bovinus & 2 & \\
\hline \multirow[t]{2}{*}{ Евро-байкальские (5) } & Температные (3) & $\begin{array}{l}\text { H. lundbecki } \\
\text { T. miki } \\
\text { A. fulvus } \\
\end{array}$ & 7 & \multirow[t]{2}{*}{11} \\
\hline & Бореомонтанные (2) & $\begin{array}{l}\text { H. kaurii } \\
\text { H. muehlfeldi }\end{array}$ & 4 & \\
\hline Восточно-европейско-байкальский (1) & Температные (1) & Ch. concavus & 2 & 2 \\
\hline Евро-ленские (1) & Температные (1) & H. ciureai & 2 & 2 \\
\hline Центрально-палеарктические (1) & Бореальные (1) & Hp. orientalis & 2 & 2 \\
\hline \multirow{2}{*}{$\begin{array}{l}\text { Центрально-восточно-палеаркти- } \\
\text { ческие (9) }\end{array}$} & Бореальные (5) & $\begin{array}{l}\text { A. pallitarsis } \\
\text { Ch. suavis } \\
\text { H. astur } \\
\text { H. brevis } \\
\text { H. pavlovskii }\end{array}$ & 11 & \multirow[t]{2}{*}{21} \\
\hline & Бореомонтанные (4) & $\begin{array}{l}\text { Ch. makerovi } \\
\text { Hm. tamerlani } \\
\text { H. olsoi } \\
\text { H. tarandinoides }\end{array}$ & 9 & \\
\hline \multicolumn{3}{|l|}{ Всего: } & 100 & 100 \\
\hline
\end{tabular}

разии. Встречается от Скандинавии на западе до Магаданской области на востоке. В наших сборах полностью отсутствовал. В сборах других авторов встречается редко [1].

H. tarandina - достаточно распространенный вид таежной зоны. Имеет подобный ареал, но в отличие от Ch. divaricatus H. tarandina имеет более широкое распространение на Дальнем Востоке. В наших сборах довольно часто встречаемый вид, однако общая доля его не высока.

Бореомонтанные виды - H. bimaculata, $H$. distinguenda и H. nigricornis - имеют обширный ареал в пределах таежной и лесной 
зон Евразии. Кроме того, они встречаются на Кавказе, в горах Тянь-Шаня и Алтая. В средней тайге эти виды довольно широко распространены. Причем H. bimaculata является доминантным видом, а H. nigricornis в наших сборах полностью отсутствовал.

Трансевразиатские температные виды, как и вообще все температные виды, имеют значительное распространение в пределах широкой составляющей их ареала. При этом они распространены в бореальном и суббореальном поясах Евразии [2]. В средней тайге нами найден трансевразиатский температный вид - H. montana.

H. montana - распространен как в бореальном, так и в суббореальном поясах Евразии. Однако на Кавказе, Тянь-Шане и Памире этот вид представлен не номинативной формой, образует соответствующие подвиды [6]. В наших сборах $H$. montana встречается часто и наряду с этим является субдоминантом.

III. Западно-центрально-палеарктические виды

В эту группу входят виды, широко распространенные в лесных районах Европы и отчасти Сибири. Южная граница ареала их обитания охватывает Северную Америку, Ближний Восток, Среднюю и Центральную Азию [2]. Для средней тайги отмечен 21 западно-центрально-палеарктический вид, что составляет $49 \%$ от фауны слепней этого региона.

По характеру распространения этих видов на восток мы выделили следующие подтипы ареала.

Евро-сибиро-среднеазиатские - характерны для эврибионтных видов, часто связаны с интразональными стациями умеренного пояса, граница их распространения проходит по линии Алтай - Тянь-Шань - Памир. С этим типом ареала отмечены следующие виды слепней: Ch. relictus, T. autumnalis, T. bromius, T. Glaucopis. Это $9 \%$ от всей фауны слепней региона.

Евро-обские (европейско-западносибирские) виды составляют 23 \% в структуре фауны слепней изучаемой территории. К этой группе относятся лесные виды, которые приспособились к мягким условиям приатлантических территорий и к континентальному климату Западной Сибири. При этом повышение континентальности климата Сибири и муссонный климат Дальнего Востока препятствуют их продвижению на восток [2]. С этим типом ареала отмечены следующие виды слепней: Ch. rufipes, Ch. sepulcralis, Hm. subcylindrica, $\mathrm{Hm}$. pluvialis, Hp. pellucens, T. bovinus, T. maculicornis, A. Rusticus. Среди них следует отметить Ch. Rufipes. По данным Н.Г. Олсуфьева [6], он является лесостепным. Ареал Ch. rufipes простирается от Средней и Северной Европы до Западной Сибири. Единственный вид, зарегистрированный в средней тайге, не являющийся кровососом. К бореальным видам следует отнести $H$. nitidifrons confiformis, являющийся таежным видом [6]. Он распространен в пределах таежной и лесной зон Центральной и Северной Европы, Урала и Западной Сибири. Отмечен во всех районах исследований. В наших сборах является субдоминантом. Из полизональных видов отмечен вид T. bovinus.

Евро-байкальские (европейско-южносреднесибирские) виды широко распространены в Европе, в Сибири их ареал сужается в районе Байкала, однако некоторые из них проникают восточнее Монголии. В фауне слепней средней тайги Западной Сибири они составляют $11 \%$. К ним относятся $H$. lundbecki, T. miki, A. fulvus, $H$. kaurii, $H$. muehlfeldi.

Евро-ленские (европейско-восточносибирские) виды представлены одним видом H. ciureai.

Восточно-европейско-байкальские виды. На территории средней тайги Западной Сибири встречается лишь один вид из этой группы - Ch. concavus. Он отнесен к восточно-европейско-сибирским суббореальным видам. Встречается от западной части Евразии до Дальнего Востока. В пределах средней тайги отмечается в Томской области.

IV. Центрально-палеарктические слепни представлены на территории средней тайги Западной Сибири только одним видом Hp. orientalis.

Центрально-восточно-палеарктические виды слепней в структуре фауны региона составляют 21\%: A. pallitarsis, Ch. suavis, $H$. astur, H. brevis, H. pavlovskii, Ch. makerovi, Hm. tamerlani, H. olsoi, H. tarandinoides. Это виды, ареал которых охватывает Сибирь, Кавказ, Монголию, Северный Китай и Дальний Восток.

Фауна слепней средней тайги Западной Сибири довольно разнообразна. Однако ее основу образуют западно-центрально-палеарктические виды (49 \%), центрально-восточно-палеарктические (21 \%), трансголарктические $(14 \%)$ и трансевразиатские $(14 \%)$. На долю центрально-палеарктических видов приходится только $2 \%$.

Нами проведено сравнение фауны слепней ХМАО-Югры и Томской области, что отражено в табл. 2.

На табл. 2 видно, что на сравниваемых территориях количество видов слепней практически одинаковое. На территории ХМАОЮгры зарегистрировано 32 вида слепней, в Томской области - 34 вида, но сходство фаун по Жаккару составляет всего 53,5 \%. Тем са- 
Сравнительный анализ фауны слепней ХМАО-Югры и Томской области по характеру распространения слепней

\begin{tabular}{|c|c|c|c|}
\hline Вид слепней & $\begin{array}{c}\text { Характер } \\
\text { распространения }\end{array}$ & ХМАО-Югра & $\begin{array}{l}\text { Томская } \\
\text { область }\end{array}$ \\
\hline Ch. nigripes & \multirow{6}{*}{$\begin{array}{l}\text { Трансголарктические } \\
\text { бореальные }\end{array}$} & + & + \\
\hline H. aequetincta & & + & \\
\hline H. arpadi & & + & + \\
\hline H. lurida & & + & + \\
\hline H. sexfasciata & & & + \\
\hline T. lapponicus & & + & + \\
\hline Ch. divaricatus & \multirow{2}{*}{$\begin{array}{l}\text { Трансевразиатские } \\
\text { бореальные }\end{array}$} & + & + \\
\hline H. tarandina & & + & + \\
\hline H. bimaculata & \multirow{3}{*}{ бореомонтанные } & + & + \\
\hline H. distinguenda & & & + \\
\hline H. nigricornis & & + & + \\
\hline H. montana & температный & + & + \\
\hline & $\begin{array}{l}\text { Западно-центрально-пале- } \\
\text { арктические }\end{array}$ & & \\
\hline Ch. relictus & \multirow{4}{*}{$\begin{array}{l}\text { Евро-сибиро-среднеазиатские } \\
\text { температные }\end{array}$} & + & + \\
\hline T. autumnalis & & + & \\
\hline T. bromius & & + & + \\
\hline T.glaucopis & & + & \\
\hline Ch. rufipes & \multirow{7}{*}{$\begin{array}{l}\text { Евро-обские } \\
\text { температные }\end{array}$} & + & + \\
\hline Ch. sepulcralis & & + & \\
\hline Hm. subcylindrica & & + & + \\
\hline Hm.pluvialis & & + & + \\
\hline Hp.pellucens & & + & \\
\hline T. bovinus & & + & + \\
\hline $\begin{array}{l}\text { T. maculicornis } \\
\text { A. rusticus }\end{array}$ & & $\begin{array}{l}+ \\
+\end{array}$ & + \\
\hline H. nitidifrons confiformis & бореальные & + & + \\
\hline T. bovinus & полизональный & + & + \\
\hline H. ciureai & $\begin{array}{l}\text { Евро-ленские } \\
\text { температные }\end{array}$ & + & + \\
\hline H. lundbecki & \multirow{3}{*}{$\begin{array}{l}\text { Евро-байкальские } \\
\text { температные }\end{array}$} & + & + \\
\hline T. miki & & + & \\
\hline A. fulvus & & + & + \\
\hline H. kaurii & \multirow{2}{*}{ бореомонтанные } & + & + \\
\hline H. muehlfeldi & & + & + \\
\hline Ch. concavus & $\begin{array}{l}\text { Восточно-европейско-байкаль- } \\
\text { ский температный }\end{array}$ & & + \\
\hline Hp. orientalis & $\begin{array}{l}\text { Центрально-палеарктический } \\
\text { бореальный }\end{array}$ & & + \\
\hline A. pallitarsis & \multirow{5}{*}{$\begin{array}{l}\text { Центрально-восточно-пале- } \\
\text { арктические } \\
\text { бореальные }\end{array}$} & & + \\
\hline Ch. suavis & & & + \\
\hline H. astur & & & + \\
\hline H. brevis & & & + \\
\hline H. pavlovskii & & + & \\
\hline Ch. makerovi & \multirow{4}{*}{ бореомонтанные } & & + \\
\hline Hm. tamerlani & & & + \\
\hline H. olsoi & & & + \\
\hline H. tarandinoides & & + & \\
\hline
\end{tabular}

Примечание: «+» - наличие видов слепней. 
мым фауны слепней ХМАО-Югры и Томской области, хотя и находятся в пределах одной подзоны средней тайги Западной Сибири, имеют существенные различия в видовом составе слепней.

В ХМАО-Югре отсутствуют центрально-восточно-палеарктические (Ch. makerovi, Ch. suavis, Hm. tamerlani, A. pallitarsis, H. olsoi, $H$. astur, H. brevis) виды. Территория ХМАОЮгры является западной границей их ареала. Не зарегистрирован также восточно-европейско-байкальский Ch. concavus. Кроме того, не найден трансголарктический бореальный вид $H$. sexfasciata и трансевразиатский вид $H$. distinguenda. Также не обнаружен на территории ХМАО-Югры и центральнопалеарктический вид Hp. orientalis.

В то же время на территории ХМАО-Югры отмечены виды слепней, отсутствующие в Томской области. Это некоторые западноцентрально-палеарктические виды: $\mathrm{Hp}$. pellucens, Ch. sepulcralis, T. autumnalis, T. glaucopis, T. maculicornis, T. miki. Территория ХМАOЮгры является восточной границей ареала этих видов. Кроме того, в Томской области не найден трансголарктический $H$. aequetincta.

Выводы. Река Обь для большинства видов слепней, обитающих в таежной зоне Западной Сибири, является границей их ареала обитания. Для некоторых видов, наоборот, дает возможность проникновения в различные физико-географические зоны. Это явление характерно вообще для крупных рек, по долинам которых слепни распространяются на обширные территории.

Географическое положение исследованного нами региона наглядно отражается на соотношении видов слепней, имеющих тот или иной характер распространения.

\section{СПИСОК ЛИТЕРАТУРЫ}

1. Виолович Н.А., Гомоюнова Н.П. К фауне и экологии слепней (Diptera, Tabanidae) степной зоны
Западной Сибири // Изв. Сиб. отд. Академии Наук CCСР. - 1964. - Т. 4. - Вып. 3. - С. 108-113.

2. Городков К.Б. Ареалы насекомых Европейской части СССР. - Л.: Наука, 1984. - 256 с.

3. Унификация методов учета численности кровососущих двукрылых насекомых / Т.С. Детинова [и др.] // Мед. паразитол. и паразитарные болезни. - 1978. - Т. 47. - Вып. 5. - С. 84-91.

4. Духин В.В., Тюмасева З.И., Гуськова Е.В. Слепни (Diptera, Tabanidae) средней тайги Западной Сибири. - Челябинск: Изд-во ЮУрГГПУ, 2016. - 126 с.

5. Лямин М.Я. Видовой состав и пространственное распределение слепней (Diptera, Tabanidae) Южного Урала // Вестник ЧГПУ. - Серия 10. - Экология. Валеология. Педагогическая психология. - 2002. - № 2. - С. 49-67.

6. Олсуфьев Н.Г. Фауна СССР. Насекомые двукрылые. Слепни. Семейство Tabanidae. - Л.: Наука, 1977. - Т. 7. - Вып. 2. - 436 с.

7. Сабиров 3.Г. К изучению фауны и биологии слепней Сургутского района Тюменской области // Проблемы борьбы с гнусом. - М., 1970. С. $47-55$.

8. Скуфьин К.В. Методы сбора и изучения слепней. - Л.: Наука, 1973. - 202 с.

Тюмасева Зоя Ивановна, $\partial-p$ пед. наук, канд. биол. наук, проф., зав. кафедрой безопасности жизнедеятельности и медико-биологических дисииплин, Южно-Уральский государственный гуманитарно-педагогический университет. Россия.

454080, г. Челябинск, просп. Ленина, 69.

Тел.: (351) 216-57-91; e-mail: zit@cspu.ru.

Духин Владислав Васильевич, канд. биол. наук, ведущий сотрудник, Инженерно-технический центр, 2. Сургут. Россия.

628400, г. Сургут, Тюменская обл., ул. Лермонтова, 90. Тел.: (3462) 34-57-18.

Гуськова Елена Владимировна, канд. биол. наук, доиент кафедры «Зоология и физиология», Алтайский государственный университет. Россия.

656049, г. Барнаул, просп. Ленина, 61.

Тел.: (3852) 29-12-21.

Ключевые слова: слепни; зоогеографический анализ; насекомые; классификация; фауна.

\section{THE ZOOGEOGRAPHICAL ANALYSIS OF WEST SIBERIA MIDDLE TAIGA GADFLIES}

Duhin Vladislav Vasilevish, Candidate of Biological Sciences, Leading Researcher, Engineering And Technical Center. Russia.

Tumaseva Zoya Ivanovna, Doctor of Pedagogical Sciences, Candidate of Biological Sciences, Professor, Head of the chair "Life Safety and Medical-Biological disciplines", South Ural State Humanitarian Pedagogical University. Russia.

Guskova ElenaVladimirovna, Candidate of Biological Sciences, Associate Professor of the chair "Zoology and Physiology”, Altai State University. Russia.
Keywords: gadflies; zoogeographical analysis; insect; classification; fauna.

The article analyzes gadflies in Middle Taiga zone of West Siberia. The article gives the characteristic of gadflies of this region: 6 boreal transgolarctic species are described; 7 belong to transeuropeanoriental species; the largest number of species of gadflies (21 species) are the westerncentralpalearctic species for the middle taiga. It is given a comparative analysis of gadflies fauna of Tomsk Region and Khanty-Mansiisk Autonomous District-Ugra. 